\title{
Growth performance and nutrient utilization of post fingerlings Clarias gariepinus fed varied levels of biscuit waste
}

Agbebi., O.T., Sofela, S.O., Idowu, M.A. and Cole, A.O.

Department of Aquaculture and Fisheries Management, Federal University of Agriculture, Abeokuta, Ogun State, Nigeria. PMB 2240, Abeokuta, Nigeria.

\begin{abstract}
A feeding trial was conducted to determine the effect of biscuit waste meal on the growth performance and utilization of Clarias gariepinus juveniles. A total of 300 juveniles of average weight $8.85 \mathrm{~g}$ were randomly divided into five Treatments, each Treatment had three replicates. Twenty juveniles were distributed into each happa $\left(0.7 \mathrm{~m}^{3}\right)$. The happa were suspended to $3 / 4$ of their volume using kuralon ropes carefully tied round the bamboo poles across the concrete tanks. Five diets containing $40 \%$ crude protein were formulated in which maize was replaced with biscuit waste meal at treatment; Diet 1 (TD1) 0\%, 25\% (TD2), 50\% (TD3), 75\% (TD4), 100\% (TD5) levels. The fish were fed at 3\% body weight per day for 10weeks. The results showed that biscuit waste was most suitable as an energy supplement when incorporated at 25\% replacement (TD2) with maize. TD1 had the highest weight gain followed by TD2, TD3, TD4 and TD5 respectively. There were no significant differences $(P>0.05)$ in the growth response in TD1 (0\%), TD2 (25\%) and TD3 (50\%). It is therefore concluded that biscuit waste meal is a cheap source of non conventional energy source which can be used favorably to replace maize (25\% inclusion level) as an energy source in the diets of C. gariepinus.
\end{abstract}

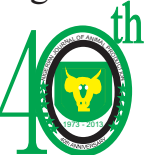

Keywords: Treatment, Biscuit waste, Net hapa, Juveniles, Crude protein

\section{Introduction}

In the developing world, fish is a highly acceptable food that supplies as much as 40 percent of all animal protein of the countries where fish is the main source of animal protein. The poor spends proportionally higher cost on fish than on meat or other sources of animal protein (Amoa et al., 2006). This demand is greater in the tropics with increasing rising human population (Andrew, 2001). The per capita consumption of aquatic foods in the tropics, which has well over 90 percent of the world population growth, may be maintained at $14.5 \mathrm{~kg} /$ capita, if there is a corresponding increase in fish supply (Andrew, 2001). Nigerians are large fish consumers with a high per capita consumption but has low per capital supply of aquatic animal food products estimated at $9.50 \mathrm{~kg} /$ year (Alberts et al., 2013). From the projected populations and fish demand in Nigeria from year 2006-2025, a drop in the availability of fish will have a detrimental effect on the nutritional status of the citizenry particularly in places where the contribution of fish is significant to the protein intake of the people. The high cost and shortage of commercial feeds for agriculture ventures in Nigeria places constraint on the successful operation of intensive aquaculture business (AkegbejoSamsons, 2004). Utilization of compounded commercial feeds is an acceptable practice, but there is a need for feed formulation strategies, that are aimed at using more available feed stuffs (biscuit waste) as substitutes for conventional feed ingredients (soybean, maize and fish meal etc) as this will help to give desired result at a cheaper feed cost.

The major source of metabolizable energy 
in most compounded diets for fish and livestock is maize (Fagbenro et al., 1992). However, the increasing prohibitive cost of this commodity as a result of its many competing uses (especially in developing African countries) has made it necessary to evaluate other ingredients to replace maize with cheaper carbohydrates (Olurin et al., 2006). However, the use of biscuit waste is yet to be fully exploited in fish diet.

Therefore, this study aims at evaluating the growth performance and the optimal inclusion of biscuit waste in diet of $C$. gariepinus juveniles.

\section{Materials and methods}

This research was carried out at the rearing facility of the Department of Aquaculture and Fisheries Management, Federal University of Agriculture, Abeokuta, The experimental layout was in fish happa nets $\left(0.7 \mathrm{~m}^{3}\right)$ suspended by bamboo poles in an outdoor concrete tank ( $5 \mathrm{~m} \times 3 \mathrm{~m} \times 1.5 \mathrm{~m})$. Fifteen (15) hapas $\left(0.7 \mathrm{~m}^{3}\right)$ were suspended to $3 / 4$ of their volume, using kuralon twine (No 15), tied to carefully arranged bamboo poles. The concrete tank was filled to a considerable volume and continually supplied with water to sustain optimal medium and to preclude primary productivity.

African catfish (C. gariepinus) juveniles (average weight $8.85 \mathrm{~g}$ ) were obtained from a Private Fish Farm and acclimatized for 5 days, with diet before the commencement of the experiment.

Biscuit waste was purchased from the grocery company, Yale Foods Nigeria Limited, Ibadan and the waste was properly grounded into fine particles for perfect homogenizing with other ingredients. Five iso-nitrogenous diets were formulated ( $40 \%$ crude protein) in which maize $(10.81 \%$ crude protein- Table 1$)$ was progressively replaced with biscuit waste
$(10.36 \%$ crude protein- Table 2$)$ at $25 \%$, $50 \%, 75 \%$, and $100 \%$ levels. The feed was pelletized into $2 \mathrm{~mm}$ diameter, sun dried for few days and stored in polythene bags.

The experimental fish were randomly distributed at the rate of 20 fish per happa. Each Treatment was triplicated. Fish were fed at 3\% body weight twice daily for the period of the experimental diet (10 weeks). The fish were batch - weighed weekly with an electronic balance (Mettler BD 601) and the amount of feed was adjusted accordingly. At the beginning and the end of the experiment, five fish were collected from each diet Treatment, sacrificed for carcass analysis.

Growth performance

Fish growth and nutrient utilization parameters were calculated as follows:

Percentage weight gain PWG $(\%)=$ Final mean body weight $\times 100$

Initial mean body weight

Specific Growth Rate $=$ $\underline{\mathrm{L}}_{\mathrm{n}} \underline{\mathrm{W}}_{2}-\mathrm{L}_{\mathrm{n}} \underline{\mathrm{W}}_{1} \quad \mathrm{x} \quad 100$ Time (days)

$\mathrm{W}_{1}=$ initial weight gained

$\mathrm{W}_{2}=$ final weight gained

$\mathrm{L}_{\mathrm{n}}=$ natural logarithm

Protein Efficiency Ratio = Mean weight gain

Average protein fed

Average protein fed $=$ feed intake $x \%$ C.P offed

Weight gain $(\mathrm{g})=\mathrm{W}_{2}-\mathrm{W}_{1}$

Feed Conversion Ratio

$=\quad$ Weight of feed $(\mathrm{g})$

Weight gain $(\mathrm{g})$ 
Agbebi., Sofela, Idowu, and Cole

Table 1: Proximate composition of feed ingredients.

\begin{tabular}{lllllll}
\hline & $\begin{array}{l}\text { Crude } \\
\text { Protein }(\%)\end{array}$ & $\begin{array}{l}\text { Ether Extract } \\
(\%)\end{array}$ & $\begin{array}{l}\text { Crude } \\
(\%)\end{array}$ & Fibre & Ash (\%) & NFE (\%) \\
\hline Fish meal & 67.68 & 4.1 & 1.31 & 14.8 & 8.00 \\
$\begin{array}{l}\text { Soybean meal } \\
\text { Groundnut }\end{array}$ & 45.3 & 18.0 & 5.0 & 4.6 & 10.0 \\
$\begin{array}{l}\text { Cake meal } \\
\text { Maize }\end{array}$ & 10.81 & 8.80 & 4.31 & 13.8 & 10.9 \\
\hline
\end{tabular}

\section{Mortality rate $=$}

No of fish dead at end of the experiment $\times \quad 100$

No of fish at the beginning of the experiment

Statistical Analysis: The growth performance and feed utilization were analyzed statistically using one way analysis of variance (ANOVA), (Steel and Torie,1980), and the differences among means were tested for significance $(\mathrm{p}=$ 0.05) (Duncan, 1955) using SPSS 16.0 statistical package.

Water Parameter: In the course of the experiment, the essential physico-chemical parameters were monitored and measured weekly. Water temperature, Dissolved oxygen and $\mathrm{pH}$ were determined using a testing kit

\section{Results}

Table 3 shows the composition in percentage of the five iso-nitrogenous diets formulated at optimal crude protein $(40 \%)$ in which maize was progressively replaced with biscuit waste at $25 \%, 50 \%, 75 \%$, and $100 \%$ levels. Proximate composition of major ingredients were determined (Table $1 \&$ 2) and hence used in the formulation of diets.
The proximate compositions of the five formulated iso-nitrogenous diets were determined in Table 4 to reveals any deviations from the control diet. Crude protein (C.P) remained approximately at optimal level $(40 \%)$. Crude fibre surprisingly decreased while Ash content increased.

Fish carcass analysis prior to (initial) and after the experiment (final) are presented in Table 5 below. The result shows appreciable increase in all parameters for each treatment diet over the 10 weeks feeding trial indicating all treatment diets were utilized by $C$. gariepinus

Table 6 shows the mean weekly growth trend of C. gariepinus fed various level of biscuit waste of the ten weeks feeding trial. Observable changes in weight $(\mathrm{g})$ within the first few weeks show the acceptability of the treatment diet although at the different levels. At the end of the experiment treatment diet five (TD5- 25\% inclusion) recorded the least weight while treatment diet two (TD2- 75\% inclusion) recorded highest

Table 2: Proximate analysis of Biscuit waste.

\begin{tabular}{|c|c|c|c|c|c|}
\hline & $\begin{array}{l}\text { Crude } \\
\text { Protein (\%) }\end{array}$ & $\begin{array}{l}\text { Ether Extract } \\
(\%)\end{array}$ & $\begin{array}{l}\text { Crude Fibre } \\
(\%)\end{array}$ & Ash (\%) & NFE $(\%)$ \\
\hline $\begin{array}{l}\text { Biscuit } \\
\text { Waste }\end{array}$ & 10.36 & 4.67 & 5.98 & 10.21 & 6.84 \\
\hline
\end{tabular}


Table 3: Percentage and proximate composition of experimental diets.

\begin{tabular}{lcllll}
\hline Components & TD $1,0 \%$ & TD2, $25 \%$ & TD $3,50 \%$ & TD $4,75 \%$ & TD $5,100 \%$ \\
\hline Biscuit Waste meal & - & 5.84 & 11.68 & 17.53 & 23.37 \\
Maize & 23.37 & 17.53 & 11.69 & 5.84 & - \\
Soybean meal & 27.56 & 27.56 & 27.56 & 27.56 & 27.56 \\
Fish meal & 27.56 & 27.56 & 27.56 & 27.56 & 27.56 \\
Groundnut Cake & 14.26 & 14.26 & 14.26 & 14.26 & 14.26 \\
Vegetable Oil & 5.00 & 5.00 & 5.00 & 5.00 & 5.00 \\
Calcium Phosphate & 0.50 & 0.50 & 0.50 & 0.50 & 0.50 \\
Vitamin C & 0.10 & 0.10 & 0.10 & 0.10 & 0.10 \\
Salt & 0.15 & 0.15 & 0.15 & 0.15 & 0.15 \\
Lysine & 0.25 & 0.25 & 0.25 & 0.25 & 0.25 \\
Methionine & 0.25 & 0.25 & 0.25 & 0.25 & 0.25 \\
Premix & 1.00 & 1.00 & 1.00 & 1.00 & 1.00 \\
\hline
\end{tabular}

Table 4: Proximate composition of experimental diets.

\begin{tabular}{|c|c|c|c|c|c|}
\hline & TD1, 0\% & TD2, 25\% & TD3, 50\% & TD4, 75\% & TD5, $100 \%$ \\
\hline Moisture (\%) & 9.10 & 9.43 & 8.45 & 8.88 & 8.71 \\
\hline NFE (\%) & 37.80 & 36.72 & 35.85 & 37.05 & 35.72 \\
\hline $\begin{array}{l}\text { Crude } \\
\text { protein (\%) }\end{array}$ & 39.70 & 39.30 & 41.00 & 40.08 & 40.90 \\
\hline $\begin{array}{l}\text { Crude fibre } \\
(\%)\end{array}$ & 4.28 & 4.01 & 3.50 & 3.58 & 4.08 \\
\hline $\begin{array}{l}\text { Ether extract } \\
(\%)\end{array}$ & 6.89 & 7.01 & 6.76 & 6.18 & 6.97 \\
\hline Ash (\%) & 2.23 & 3.50 & 4.44 & 4.23 & 3.62 \\
\hline
\end{tabular}

*NFE $($ Nitrogen free extract $)=100-(\mathrm{MC}+\mathrm{C} . \mathrm{P}+\mathrm{ASH}+\mathrm{C} . \mathrm{F}+\mathrm{E} . \mathrm{E})$ 
Agbebi., Sofela, Idowu, and Cole

Table 5: Initial and final analysis of fish carcass.

\begin{tabular}{|c|c|c|c|c|c|c|}
\hline & \multirow[t]{2}{*}{ INITIAL } & \multicolumn{5}{|c|}{ FINAL TREATMENT } \\
\hline & & TD1 & TD2 & TD3 & TD4 & TD5 \\
\hline $\begin{array}{l}\text { Moisture } \\
(\%)\end{array}$ & 19.18 & 20.09 & 21.00 & 20.60 & 27.40 & 26.00 \\
\hline Ash (\%) & 2.99 & 7.6 & 7.62 & 7.4 & 7.10 & 7.25 \\
\hline $\begin{array}{l}\text { Crude } \\
\text { protein }(\%)\end{array}$ & 53.07 & 66.60 & 67.42 & 63.92 & 60.12 & 59.66 \\
\hline $\begin{array}{l}\text { Crude fibre } \\
(\%)\end{array}$ & 0.6 & 0.66 & 0.62 & 0.84 & 0.9 & 1.10 \\
\hline Fat (\%) & 11.20 & 14.98 & 15.2 & 16.42 & 10.6 & 10.1 \\
\hline
\end{tabular}

after the control diet (TD1- 0\% inclusion).

Table 7 shows the calculated growth parameters for all treatments and their significant differences.

Table 9 shows the mean weekly values of physico-chemical parameters recorded during the entire feed period.
All parameters were within the prescribed range for rearing of $C$. gariepinus according to Viveen et al. (1977).

\section{Discussion}

In this study, catfish juveniles grew and survived well on all experimental diets

Table 6: Mean weekly growth trend of Clarias gariepinus fingerlings fed various level of biscuit waste based diets.

\begin{tabular}{llllll}
\hline Weeks & TD1 $(\mathrm{g})$ & TD2 $(\mathrm{g})$ & TD3 $(\mathrm{g})$ & TD4 $(\mathrm{g})$ & TD5 $(\mathrm{g})$ \\
\hline 0 & 8.89 & 8.89 & 8.84 & 8.25 & 9.37 \\
1 & 11.61 & 11.13 & 10.45 & 11.99 & 11.78 \\
2 & 14.00 & 13.67 & 13.51 & 13.23 & 13.11 \\
3 & 16.12 & 15.78 & 15.70 & 15.10 & 14.87 \\
4 & 19.90 & 19.10 & 18.97 & 18.10 & 16.20 \\
5 & 20.60 & 20.24 & 19.65 & 19.00 & 17.05 \\
6 & 22.15 & 22.05 & 21.73 & 19.90 & 17.92 \\
7 & 23.97 & 23.66 & 23.01 & 20.76 & 18.55 \\
8 & 25.03 & 24.87 & 23.87 & 21.33 & 19.01 \\
9 & 26.73 & 25.04 & 24.05 & 22.31 & 19.69 \\
10 & 28.01 & 26.54 & 25.10 & 22.98 & 20.51 \\
\hline
\end{tabular}


Nutrient utilization of post fingerlings fed varied levels of biscuit waste

Table 7: Growth Response and Nutrient utilization of Clarias gariepinus fingerlings fed various levels of biscuit waste meal diets.

\begin{tabular}{|c|c|c|c|c|c|}
\hline Parameters & TD1 & TD2 & TD3 & TD4 & TD5 \\
\hline $\begin{array}{lr}\begin{array}{l}\text { Initial } \\
\text { body }\end{array} & \text { mean } \\
\text { weight }\end{array}$ & $8.89 \pm 2.56$ & $8.89 \pm 2.31$ & $8.84 \pm 2.14$ & $8.85 \pm 2.40$ & $8.87 \pm 2.29$ \\
\hline $\begin{array}{l}(\mathrm{g}) \\
\text { Final mean } \\
\text { body weight } \\
(\text { o })\end{array}$ & $28.01 \pm 0.33^{\mathrm{a}}$ & $26.54 \pm 0.23^{\mathrm{ab}}$ & $25.10 \pm 0.65^{b}$ & $22.98 \pm 0.48^{c}$ & $20.51 \pm 0.45$ \\
\hline Weight gained & $19.12 \pm 0.22$ & $17.61 \pm 0.18^{\mathrm{ab}}$ & $16.26 \pm 0.19^{b}$ & $14.73 \pm 0.21^{\mathrm{c}}$ & $11.14 \pm 0.13^{\mathrm{d}}$ \\
\hline $\begin{array}{l}\text { Specific } \\
\text { growth rate } \\
\text { per day }(\%)\end{array}$ & $2.07 \pm 0.21$ & $1.86 \pm 0.29^{b}$ & $2.01 \pm 0.26^{\mathrm{c}}$ & $1.87 \pm 0.21^{\mathrm{d}}$ & $1.83 \pm 0.15^{\mathrm{e}}$ \\
\hline $\begin{array}{l}\text { Protein } \\
\text { efficiency ratio }\end{array}$ & $1.45 \pm 0.07^{\mathrm{a}}$ & $0.97 \pm 0.1^{\mathrm{a}}$ & $1.21 \pm 0.05^{\mathrm{a}}$ & $0.97 \pm 0.10^{b}$ & $1.21 \pm 0.07^{\mathrm{b}}$ \\
\hline $\begin{array}{l}\text { Feed } \\
\text { conversion } \\
\text { ratio }(\mathrm{g})\end{array}$ & $1.74 \pm 0.29$ & $2.55 \pm 0.31^{\mathrm{a}}$ & $2.06 \pm 0.54^{\mathrm{a}}$ & $2.58 \pm 0.59^{\mathrm{a}}$ & $2.07 \pm 0.41$ \\
\hline $\begin{array}{l}\text { Mean protein } \\
\text { intake (g) }\end{array}$ & 9.98 & 11.32 & 9.38 & 9.88 & 5.72 \\
\hline $\begin{array}{ll}\text { Mean feed } \\
\text { intake (g) }\end{array}$ & 24.95 & 28.29 & 23.45 & 24.70 & 14.30 \\
\hline $\begin{array}{l}\text { Survival rate } \\
(\%)\end{array}$ & 75.0 & 63.0 & 70.0 & 65.0 & 62.0 \\
\hline
\end{tabular}

a, b, c, Means followed by the deferent superscripts along the same row are significant different $(\mathrm{P}<0.005)$.

KEY: TD1 ( $0 \%$ BISCUIT WASTE MEAL, 100\% MAIZE) TD2 (25\% BISCUIT WASTE MEAL, 75\% MAIZE) TD3 (50\% BISCUIT WASTE MEAL, 50\% MAIZE) TD4 (75\% BISCUIT WASTE MEAL, 25\% MAIZE) TD5 (100\% BISCUIT WASTE MEAL, $0 \%$ MAIZE)

which contain varying levels of inclusion of biscuit waste. This indicates that the formulations were sufficient at $25 \%$ and $50 \%$ inclusion. This is in agreement with similar studies by (Alegbeleye et al., 2008) where maize was replaced with boiled Colocassia esculenta flour. It was observed that there was a trend of decrease in weight gain with increasing level of inclusion from $20 \%$ inclusion level. Lasisi et al. (2008) also recorded similar results. The effect of substituting sweet potato peel meal with maize in the diets of $C$. gariepinus fingerlings was studied and it was observed that $25 \%$ inclusion level was favorably tolerated.

The result of the study indicated that the best response of the diet in the growth of the catfish was observed in the Treatment diet 1 $(0 \%)$, Treatment diet $2(25 \%)$ and Treatment diet $3(50 \%)$ respectively.

Table 8: Cost Effective Analysis of the feed Ingredients

\begin{tabular}{lll}
\hline Feed Ingredients & Cost per kg (Naira) & Cost per kg (dollars) \\
\hline Maize & 80 & 0.53 \\
Biscuit waste & 35 & 0.23 \\
\hline
\end{tabular}




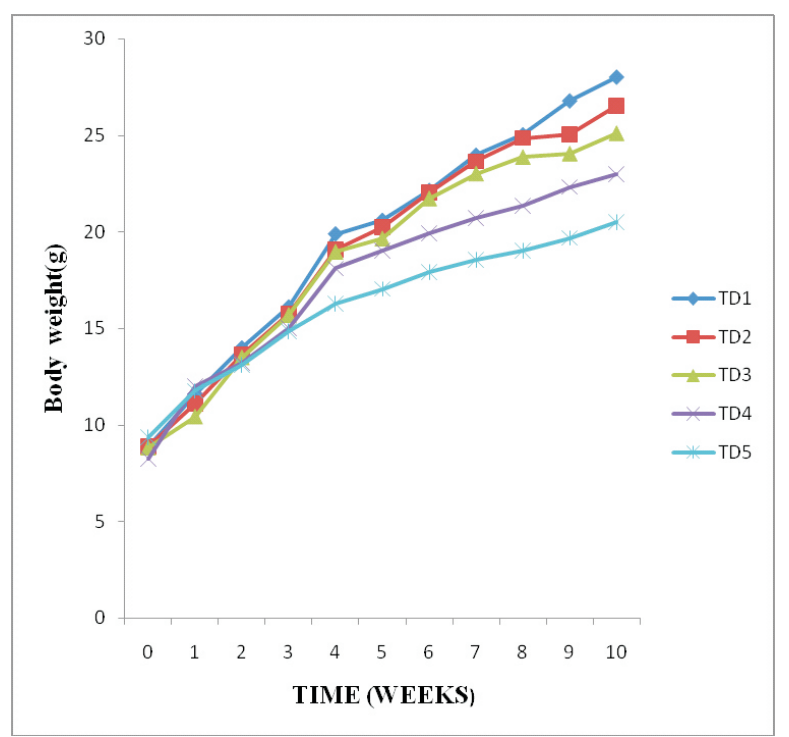

Fig 1: Graphical Illustration of the Mean Weekly Growth Rate of Clarias gariepinus Fed with Varying Levels of Biscuit Waste throughout the experimental periods.

Growth rate in terms of weight gain decreases with increase in the inclusion level of biscuit waste in Treatment diets 3, 4 and 5 respectively which is contrary to studies by (Tiamiyu et al. 2007) where an increase in growth rate was recorded for $50 \%$ and above inclusion level of Cassava flour in the diet of C. gariepinus. Biscuit waste meal used in these study has almost equal crude protein content (10.36) compared to maize (10.81), and was supposed to perform well as those fed with $100 \%$ maize (Treatment diet 1), the reason for this could possibly be the presence of a high fibre content, present in biscuit waste (5.98). The difference in amino acid profile which was inferior to that of maize could also be a reason for the result obtained in

Table 9: Mean weekly values of physico-chemical parameters during the experimental period.

\begin{tabular}{llll}
\hline Weeks & $\mathbf{p}^{\mathbf{H}}$ & Dissolved Oxygen $\mathbf{( m g / \mathbf { l } )}$ & Temperature \\
\hline $\mathbf{0}$ & 7.1 & 8.0 & 27.10 \\
$\mathbf{1}$ & 6.9 & 7.7 & 26.00 \\
$\mathbf{2}$ & 6.96 & 8.5 & 26.75 \\
$\mathbf{3}$ & 7.54 & 7.3 & 28.00 \\
$\mathbf{4}$ & 7.42 & 8.1 & 27.00 \\
$\mathbf{5}$ & 7.53 & 7.8 & 26.40 \\
$\mathbf{6}$ & 7.61 & 8.1 & 27.40 \\
$\mathbf{7}$ & 7.41 & 6.4 & 27.00 \\
$\mathbf{8}$ & 7.31 & 6.2 & 27.00 \\
$\mathbf{9}$ & 7.02 & 6.6 & 27.40 \\
$\mathbf{1 0}$ & 7.26 & 6.3 & 26.70 \\
\hline
\end{tabular}


treatment $2 \& 3$ compared to treatment 1 . This shows that biscuit waste can favorably replace maize at these inclusion levels. The study reported growth decrease with increasing inclusion levels of biscuit waste from Treatment 4 to Treatment 5. It is assumed that the anti-nutritional level is not at acute level.

The high increase in the growth rate of $C$. gariepinus in the first few weeks of culture in the study may be due to initial starvation of the fish which made them more active. This was similar to observations in juvenile Heterotis niloticus (Faturoti et.al., 1998), where an increase in growth of the fish as they were subjected to delay in feed distributed was recommended.

Table 8 shows the cost effective analysis of the feed ingredient and this research feed formulation would enhance profit margins in fish culture in Nigeria which would not permit too much dependence on commercial feeds. The grocery products such as biscuit, indomine and gala wastes are readily available in respective industries and their inclusion into fish feed as substitutes for conventional feed ingredients reduces cost of feed with encouraging growth rate performance (Agbebi et al., 2013).

The proximate analysis of the carcass of the initial fish and those fed the different experimental diets at the start and end of the experiment is represented in Table 5.0. There was increase in ash, crude fibre and fat of the final carcass analysis. Crude protein content of the carcass reduced with increase in the inclusion level of biscuit waste in the diet.

Water quality parameters of the concrete pond during the experimental period are presented in Table 9. The values observed were within the tolerant range of $C$. gariepinus. The $\mathrm{p}^{\mathrm{H}}$ was between $6.9-7.61$, dissolved oxygen $6.2 \quad-8.5 \mathrm{mg} /$ litre and temperature $26.00-29.00^{\circ} \mathrm{C}$. The physicochemical parameters of water were within the range for culturing African catfish, $C$. gariepinus and conform to the finding of Adekoya et al., (2004) recommended dissolved (DO) level of between 4$8 \mathrm{mg} /$ litre in ponds.

\section{Conclusion and Recommendation}

The Physical observation of the fish to the test diets showed that experimental fish actively accepted and fed upon the feeds all through the experimental period. Biscuit waste meal is a cheap source of non conventional energy sources which can be used favorably to replace maize in the diets of $C$. gariepinus as indicated in the cost effective analysis of Table 8 . There were no significant differences in the growth response between Treatment $1(0 \%)$, Treatment $2(25 \%)$, and Treatment 3(50\%) inclusion level. In order to collect enough biscuit waste, it is certain that no grocery company desires much waste in their production but gradual waste storage eventually mounts up for weighty waste quantity that could be enough to make up for fish feed supplement.

\section{References}

Adekoya, B.B, Olunuga O.A., Ayansanwo, T.O. and Omoyinmi, G.A.K. 2004. Manual of the second annual seminar and training workshop held at Ogun State Agriculture development Programme, OGADEP, Olabisi Onabanjo Way, Idi Aba, Abeokuta. Publisher: The Fisheries Society of Nigeria (Ogun State Chapter). Pp 52.

Agbebi, O.T, A.I Ilesanmi, W.O Alegbeleye, D.O Odulate, S.O Obasa and O.J Olaoye 2013. Growth and Heamatological Effects of Replacing Maize with Feed Wastes on the 
Juvenile Clarias gariepinus (Burchell, 1822). Journal of Fisheries and Aquatic Science, 8(4), 535-543.

Akegbejo-Samsons, Y. and J.N Ojini 2004. The use of the African locust bean Pakia biglobosa waste slurry as energy feedstuff in practical diets for Tilapia.(O. niloticus). Journal on Tropical Aquaculture. 22(4): 267-273.

Alberts G, J Tacon and M Metian 2013. Fish Matters: Importance of Aquatic Foods in Human Nutrition and Global Food Supply, Reviews in Fisheries Science, 21:1, 22-38

Alegbeleye W.O, O. Olude and N. Ramoni 2008. Effect of feeding Colocasia (Colocasia esculenta) corn flour as a part of energy supplement on growth and nutrient utilization in Clarias gariepinus (Burchell, 1822) fingerlings. In: Book of Proceedings, Fisheries Society of Nigeria (FISON) and 23rd Annual Conference Kaduna, 26th-30th October 2008. pp. 181-184

Amoa J.O, Oluwatayo I.B., and Osuntope F.K. 2006. Economics of Fish Demands in Lagos $\mathrm{S}$ t a t e , Nigeria. J. Hum. Ecol., 19 (1): 25-30.

Andrew,A.E., 2001. Fish Processing Technology in the Tropics. National Institute for $\quad \mathrm{Fr}$ e s h w a t e $\mathrm{r}$ Fisheries Research, New Bussa Nigeria. Pp 1-9.

AOAC (1990). Official methods of Analysis (14 ${ }^{\text {th }}$ edition). Association of official Analytical Chemists, Washington, DC. $1298 \mathrm{pp}$

Falaye, A.E. and O.O Olorunmuyi, 1998. Nutritive Potential of Plantain Peel Meal and Replacement Value for Maize in Diet of African Catfish (Clarias gariepinus) fingerlings. Tropical Agriculture, pp. 488-492.

Faturoti E.O, S.O Obasa and A.L Bakare 1998. Growth and nutrient utilization of Heterotis niloticus fed life maggots in sustainable utilization of Aquatic/Wetland resources. Selected papers from $9^{\text {th }} / 10^{\text {th }}$ Annual Conference of the Nigerian Association for Aquatic Sciences. Pp 182-188.

Federal Department of Fisheries, 2007. Fisheries Statistics of Nigeria, $4^{\text {th }}$ edition. Federal Department of Fisheries, Abuja, Nigeria. Pp 17-39.

Lasisi B.A, Ipinjolu J.K, Hassan WA and Omitoyin BO 2008. Growth performance of Clarias gariepinus (Burchells, 1922) fingerlings fed varying levels of sweet potato peel meal as substitute for maize. African Journal of Biotechnology Vol. 6(23), pp 485-490.

New, M.B. 1990. Compound feedstuff for shrimp culture, In M.B. New, H. de Saram and T.Singh (eds.) technical and economic aspects of shrimp farming. Pp 79-123

Olurin, R.R., E.A.A. Olojo and O.A Olukoya 2006. Growth of African Catfish Clarias gariepinus fingerlings, fed different levels of cassava. WJ Zoology Vol. 1 No. (1): 54-56.

Tiamiyu L.O and Solomon S.G 2007. Growth and nutrient utilization of varying levels toasted bambara nut (Voandzeia subtervanea) based diets for Clarias gariepinus fingerlings. In: Book of Proceedings, Fisheries Society of Nigeria (FISON) and 22nd Annual Conference Kebbi, November 12-16, 2007. Volume 1, pp: 233-235.

Viveen, W.J.A.R., Richter, C.J.J, Van Jassen, J.A.L. and Huisman, E.A. 1977. Practical Manual for the culture of the African Catfish (Clarias gariepinus). Joint publication of Directorate General International Cooperation of the Ministry of Foreign Affairs, Netherlands. Pp 94.

Received: $12 / 12 / 12$ Accepted: 03/06/13 